\title{
Antecedents of Brand Loyalty in Beverage Industry of Pakistan, Moderating Role of Brand Image
}

\author{
Muhammad Usman Javed ${ }^{* 1}$, Khurram Shahzad ${ }^{2}$ \\ Riphah International University, Islamabad, Pakistan
}

\begin{abstract}
The aim of the current study was to examine a few antecedents of brand loyalty, such as brand awareness, perceived quality, especially focusing on the moderating role of brand image. The data were collected using survey method and statistical techniques such as correlation and regression were used for analysis and interpretation of the said data. The results indicated a positive relationship between perceived quality and brand loyalty but a negative relationship between brand awareness and brand loyalty. Additionally, no moderation has been found between brand awareness, perceived quality and brand loyalty due to brand image. Furthermore, perceived quality is found to be a determinant of brand loyalty. Overall, these results demonstrated that the influence on brand loyalty varies across various variables of study. Results from this study contribute to the marketing and brand managers seeking to improve their understanding of the ever growing brand loyalty topic.
\end{abstract}

\section{Introduction}

A brand is generally defined as the name, sign, symbol, design or combination of them, that is aimed to give the goods and services recognition of a particular seller or a group of sellers and distinguish them from the competitors (Keller, 1993). Usually brands aim at assisting the buyers to meet their requirements in an optimal way, while sustaining their confidence in the worth of a product on which they had depended on previously; as doing so enhances the chances of the repeated purchase by the customer. Repeated purchase depends on the fact that a customer may get something valuable out of the purchase, to make them want to feel attached to the brand, consequently leading to the brand loyalty. From a companys standpoint, retaining such customers is much more lucrative and easier, as creating a new customer pool is not only costly but takes up much more time and effort than the former. Customer loyalty can be achieved by maintaining a healthy and treasured relationship between the customer and the brand (Raimondo et al., 2008). Companies having a large pool of buyers who are loyal to brand perform well by the virtue of increased sales and transactions, owing to their loyal customers, having a positive impact on brand and overall firm performance. Chaudhuri and Holbrook (2001) posited that a customers loyalty to the brand is one of the major factors which influences the market share of the company. Similarly, Raju et al. (1990) postulated that the brands with a larger loyal customer base have to spend

*Corresponding author.

Email: usman.javed@cust.edu.pk

http://www.jbrc.pk much less when it comes to price promotions, offers, etc. in comparison to those with less loyal clientele. The greater the difference between the loyalty rates among two brands, the stronger one is more likely to be spending on marketing in order to enhance their sales (Agrawal, 1996). The Brand loyalty has been an issue for researcher in measuring it or finding its antecedents. According to an old approach loyalty has two components behavioral loyalty as well as attitudinal loyalty. Most of researchers have tried to integrate both components, to measure it. In this particular study we will follow the stochastic approach according to which Loyalty is a behavior. In this support we made the base three of theories Social exchange theory, Social learning theory and Theory of planned behavior.

A small literature in respect of brand exists in the developing economies. In Pakistan a least research work have been carried out in academics on brand. Pakistan is a different context in respect of the culture for example According to Hofstede (1984) study of national cultural comparison Pakistan has collectivism culture it means in Pakistani culture a group orientation is common approach. These groups may contribute in brand loyalty through positive words of mouth. Another dimension is the high rate of uncertainty avoidance. At the same time the literature suggests that risk aversion may lead to brand loyalty. It means here the research should be carried out on antecedent of brand loyalty.

Furthermore, the main argument in the favor of practical implication of this research is, in Pakistan the 
out comes of the marketing efforts of different brands are quite different from the rest of the world. Antecedents of brand loyalty are less likely to be the same in developing and developed countries, alike, owing to the economic differences.

As far as the beverage industry is concerned, the linkages between customer loyalty and the growth of the industry require to be paid a bit of attention, as in the recent years the beverage industry of Pakistan has observed a significant growth. As per the interview of Chairman Pakistan Beverage Manufacturers Association, the beverage industry has an annual growth of 15 percent, with its current size of over 120 million cases per annum. Additionally, the industry has the potential of growth increase in the coming next three to five years, at the same rate (Pakistan and Gulf Economist PAGE).

The rapid current growth rate of the beverage industry brings about certain opportunities as well as threats to the marketers. The opportunity to enhance the market share due to the growth may be threatened by the increase in the potential new entrants, jumping in to cash in the present opportunities. With the increase in the competition, the firms need to vigilantly invest in order to enhance the brand loyalty, as the easy availability of the alternatives may cause the customers to switch the brands; thus providing the rationale of the study, which may help the marketers find out more about the antecedents of the brand loyalty in order to enhance theirs, to retain and win the greater market share.

\section{Literature Review}

\subsection{Brand Loyalty}

The concept of brand loyalty has been proven to be of importance for the marketers and the researchers alike over the past few years. The brand loyalty can better be defined by the help of multidimensional theory of brand loyalty. Theory argued that the brand loyalty is a biased evaluation of a brand and behavioral as well as emotional tendency towards a brand. The antecedent of brand loyalty describes how a customer begins as a new customer and reaches the stage of brand loyalty, going through certain stages. Aurier and Séré de Lanauze (2011) described that through brand evaluation, customers manifest attitudinal loyalty which ultimately has a significant and positive impact on the relationship quality. Literature suggests that brand trust has a great effect on the brand loyalty, such that, brand trust and equity ultimately result in attitudinal and behavioral loyalty (Taylor et al., 2004). Similarly, a study by Matzler et al. (2008) also documented brand trust and equity lead to loyalty, attitudinal and behavioral; while the risk aversive behavior of the customers also plays a vital role.

Along with the above mentioned factors, several studies have also focused on the personal characteristics and internal customer behavior of the customers, in order to gauge brand loyalty. Demographics have also believed to have an impact on the loyalty towards a brand. A study by Møller Jensen (2011) found that men were less likely to be brand loyal as compared to women, thus establishing that gender variable is one of the important factors to be considered while exploring the antecedents of brand loyalty. He further suggested that this could mean that the companies need to pay a special attention while advertising for men, in order to create brand loyalty. In a study focusing on the personality traits of brand, Louis and Lombart (2010) found a significant relationship between brand traits for coca cola with customer trust, commitment and attachment to the brand. Similarly, another study found that not all the dimensions of brand personality affect the brand loyalty; only extraversion is believed to have a significant impact on the loyalty (Lin, 2010). Liu and $\mathrm{Hu}$ (2011) posited that another factor which may add to the brand loyalty is the complementary products, which help enhancing the output of the core product and brand loyalty to the core brand as well. Pricing strategy also plays a certain role in the phenomenon. While studying the high priced brands, it is often noticed that brand loyalty is negatively associated with the price; whereas, for low price brands the pricing, deal promotions and the brand loyalty are positively related (Al-Rousan and Mohamed, 2010). As far as the market share and the strengths are concerned, the store brands can do so on the basis of the pricing strategy (Luis Méndez et al., 2011). Another study suggested that the usage level of the customer has an impact on the loyalty towards that particular brand (Liu, 2007); as well as the positive word of mouth, which seem to be a great source of the enhanced loyalty. Hur et al. (2011) established that brand dedicated groups spread the positive word of mouth about the brand amongst their peers, which enhances the purchase intention and ultimately brand loyalty.

Brand attachment affects the customer belief that the customer is better off with the particular brand than the other brand so as to make profitable transactions, and ultimately their dedicated conduct leads to brand loyalty (Belaid and Temessek Behi, 2011). In the context of customer loyalty, researchers have explored the dimensions of loyalty such as trust, perceived quality and cost of switching. Aydin and Özer (2005) in their study explored the antecedents of the customer loyalty. Their study results predicted that trust, perceived service quality and perceived switching cost seem to be the detrimental factors of customer loyalty. Dedicated customers are willing to pay more for a brand they recognize than the ones they dont (Srivastava, 2011). Loyalty has also been studied from the stand point of the 
employees, which is known as internal branding. Punjaisri and Wilson (2011) established that when employees have been attached to the brand for an extended time, it is important for the firm to start focusing on internal branding as it may have a positive effect on employee commitment and on brand loyalty. Similarly, the service quality of the satisfied and committed employees will be better leading to the enhanced brand loyalty (Abu-ELSamen et al., 2011).

\subsection{Perceived Quality}

Perceived quality is how a customer believes the quality of the product will be based on his or her perception. Studies found that while managing brands, managers should focus on certain ten attributes, one of which is the quality (Herstein and Zvilling, 2011). Although, customers want a good quality product at a low price, it is however quite tricky to assess what quality a customer perceives in a brand and to meet that perceived criteria (Grunert, 2005). The features of the product comprise of intrinsic and extrinsic signals of quality. The intrinsic signals influence the perceived quality; therefore, literature suggests that managers should work hard to reduce the gap between perceived and the observed quality of the product in order to enhance the customer loyalty (Nath Sanyal and Datta, 2011). Another study found that brand creditability also enhances the perceived quality which consequently affects the purchase intention, whereas, pleasure seeking behavior has believed to moderate the relationship between these variables (Hyun Baek and Whitehill King, 2011). Similarly, Akram et al. (2011) posited that when a brand is believed to be globalized, it can affect the purchase intentions by paying attention to certain features such as perceived quality and prestige, as per the perception of the customer. According to social exchange theory the human relationships are based on the cost benefit analysis. So it can be argued that the customer is likely to become loyal with the brand in which they perceived quality. The research conducted by Nguyen et al. (2011) showed that there is positive relationship between customers brand loyalty and perceived quality.

H1. Perceived quality has significant and positive impact on brand loyalty.

\subsection{Brand Awareness}

Consumer knowledge is deemed to be important factor in determining the choice of products and services the same as awareness is deemed important factor in recall and recognition. The brand awareness is a basic degree of knowledge which an individual has about a brand for example at least he recognizes the brand or recalls the brand in some state of deprivation. Keller
(2003) argued that the brand awareness is the customer knowledge on the basis of which he can identify the category of brand and know about the need which it satisfies.

According to a study conducted by Alamro and Rowley (2011), brand awareness is an antecedent of brand preference, and awareness was furthermore categorized into two groups, i.e. controllable and noncontrollable communication. They further established that in order to enhance the brand preference amongst customers, it is important to deliver to the customers. For which, advertising is believed to be the best tool, as it is used to introduce, recall and remind the customer about your product. Aravindakshan and Naik (2011) observed that when advertising is halt the ad remain in recollection of the buyers for twenty one days. Channel members also have significance in the value creation course by marketers. Gupta et al. (2010) observed that the brand knowledge is not sufficient for the resellers in a selection decision they also use to compare the brand with its delegate. Radder and Huang (2008) argued that in creating the awareness of a brand of high involvement products, the role of advertising is more important than low involvement products. Perception is the primary ingredient of consumer attitude and conduct. Rajagopal (2007) reported that it is very important what buyer perceives about a brand, so the firms are required focus and spend on the effective communication to make their consumers aware about unfamiliar brands and as a result they will be likely to make buying decision about those brands.

The customer usually sticks to the brand of which they are aware. According to social learning theory it can be argued that the brand awareness can contribute in the brand loyalty. Brand awareness basically comes from society may be from words of mouth or some other IMC tool. The type of product or service matters a lot in consumer decision. Another study on university brand posited that the customer is more likely to make a choice based on their awareness than on the reputation of the university, where different brands have same reputations (Brewer and Zhao, 2010). Nguyen et al. (2011) in their study established that brand awareness is positively linked with brand loyalty.

H2. Brand awareness has significant and positive impact on brand loyalty.

\subsection{Brand Image}

Brand image has been considered an important factor in the plethora of brand literature. Studies show that brand image can help a firm enhance its standing in the market by focusing on having a strong image (Lee et al., 2011). Similarly, in a study by Li and Hung (2009) which focused on school image, their results posited that the loyalty of the parents is more 
likely to be linked with the school image. Likewise, when a brand is expended by company, apart from the perceived quality, the fit between the parent brand and its extension also affect the overall brand image (Müge Arslan and Korkut Altuna, 2010). Brand image has been studied as a moderator in literature of brand loyalty. Although the current study is considering the antecedents like quality and awareness, brand image is also an important factor while focusing on brand loyalty. When a company promises the deliverance of better quality with an intention to enhance the loyalty, brand image also comes into the play. Brand image has been believed to have a positive relationship with the brand loyalty (Bianchi and Pike, 2011). Likewise, brand image has a significant impact on the perceived quality of the said brand as well (Chan-Olmsted and Cha, 2008). Hsieh and $\mathrm{Li}$ (2008) claimed that positive brand image will help a company to meet the perception of the customer.

Hence it can be hypothesized that:

H3. Brand image has moderating role in relationship between perceived quality and brand loyalty.

H4. Brand image has moderating role in relationship between brand awareness and brand loyalty.

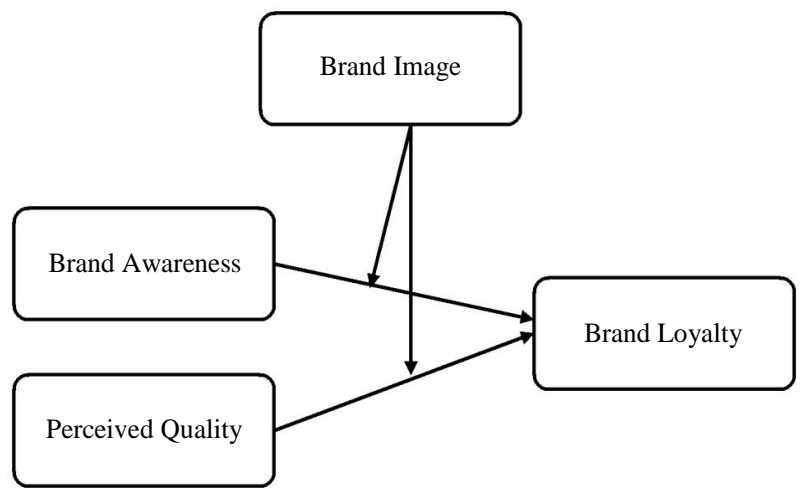

Figure 1: Conceptual Framework

\section{Research Methodology}

\subsection{Sample and Data Collection}

The aim of the current study was to examine a few antecedents of brand loyalty, such as brand awareness, perceived quality, especially focusing on the moderating role of brand image. In order to achieve the above objective quantitative method is used for data analysis. The population was students, consumers and employees. The study is descriptive in nature. Our research was a quantitative research in which we have done non probability sampling. Structure question- naire was used by using convenience sampling technique, because through this technique researcher is able to gather a large amount of information easily at very low cost. The respondent participates voluntarily and made sure that their answers will be confidential and will only be used for this investigation. In order to narrow down the focus of the study, soft drinks, such as Pepsi, Coca Cola, Sprite and $7 \mathrm{Up}$ were chosen as a focused brand. Questionnaires were distributed to 150 respondents out of which 103 were usable with $86 \%$ response rate. Out of the 130 respondents, 78 were males and 52 were females. The data were collected from Islamabad and Rawalpindi. Majority respondents fall between 18 and 35 years. The questionnaires were distributed by hand to different students, employees, and consumer and from some users online data were also collected who had access to internet.

\subsection{Measurement}

Data were collected using already developed questionnaires. In order to measure brand image, a three item questionnaire developed by Aaker (1996) and Martinez and De Chernatony (2004) was adopted. Perceived quality was measured adopting a 3 item questionnaire developed by Dodds et al. (1991) and Zeithaml (1988). Brand loyalty was measured adopting a 4 item questionnaire by Jacoby and Kyner (1973) and brand awareness, scales developed by Aaker (1996) consisting of 4 items were adopted. The five-point Likert scale was used to measure the relationship between dependent and independent variable from strongly disagree to strongly agree.

\section{Results}

The data were analyzed using SPSS, through correlation and regression analyses. The results are discussed further.

Table 4.1 shows the correlation matrix between the variables. As per the results, the correlation between brand awareness and loyalty is positive and significant at 0.23 . Similarly, brand image and loyalty also have a positive and significant correlation (0.46). The rest of the variables also show positive and significant correlation, showing that, perceived quality and brand loyalty are positively correlated at .40, whereas, awareness and brand image are correlated at a significant value of .043. Likewise, awareness and perceived quality are also positively correlated at .50 and ultimately, brand image and perceived quality were also significantly correlated at .48 .

The regression results in Table 4.2 indicate that there is a no significant relationship between brand awareness and brand loyalty, i.e. $b=0.06, t=.69, p=$ $.41>.000)$; whereas, perceived quality happens to have 
Table 4.1: Correlation Analysis

\begin{tabular}{lcccc}
\hline & Brand Loyalty & Brand & Brand Image & Perceived \\
\hline Brand Loyalty & 1 & $.23^{* *}$ & $.46^{* *}$ & $.40^{* *}$ \\
Brand Awareness & $.23^{* *}$ & 1 & $.43^{* *}$ & $.50^{* *}$ \\
Brand Image & $.46^{* *}$ & $.43^{* *}$ & 1 & $.48^{* *}$ \\
Perceived & $.40^{* *}$ & $.50^{* *}$ & $.48^{* *}$ & 1 \\
\hline
\end{tabular}

** Correlation is significant at the 0.01 level (2-tailed).

Table 4.2: Regression Analysis

\begin{tabular}{lcccc}
\hline $\begin{array}{l}\text { Predictors } \\
\text { Model }\end{array}$ & $\mathbf{R}^{2}$ & $\beta$ & $\begin{array}{c}\text { Brand Loyalty } \\
\text { T value }\end{array}$ & $\begin{array}{c}\text { Significance } \\
\mathbf{P}\end{array}$ \\
\hline Brand Awareness & 0.24 & 0.06 & 0.69 & 0.41 \\
Perceived Quality & 0.24 & 0.46 & 5.00 & 0.00 \\
\hline
\end{tabular}

Predictors: $P Q, B A$

Dependent Variable: $B L$

Table 4.3: Regression Analysis of Moderation

\begin{tabular}{lcccc}
\hline Predictors & \multicolumn{3}{c}{ Brand Loyalty } \\
Step 1 & $\mathbf{R}^{2}$ & $\beta$ & T value & Significance \\
\hline Brand Awareness & 0.10 & 0.23 & 3.83 & 0.00 \\
Perceived Quality & 0.25 & 0.50 & 6.54 & 0.00 \\
Brand Image*Quality & 0.32 & -0.14 & -0.25 & 0.80 \\
Brand image* Awareness & 0.37 & -0.42 & -0.84 & 0.39 \\
\hline
\end{tabular}

Predictors: $P Q, B A$

Dependent Variable: $B L$

a significantly positive relationship with brand loyalty at $\mathrm{p}=.000(\mathrm{~b}=.46, \mathrm{t}=5.0)$. Similarly, for the moderation, moderated regression results were found to be non significant at $\mathrm{p}=0.80(\mathrm{~b}=-.14, \mathrm{t}=-.25)$ therefore, hypothesis three is not supported, i.e. brand image moderates the relationship among perceived quality and brand loyalty. Likewise, our hypothesis four that brand image moderates the relationship between brand awareness and loyalty has also been rejected with $\mathrm{p}=.39(\mathrm{~b}=$ $-.42, \mathrm{t}=-.84)$.

\section{Discussion}

The main aim of the study was to explore the concept and implication of brand loyalty in Pakistan. Although, brand loyalty has been a well studied construct, but the cultural and consequent socioeconomic differences among cultures rendered it important to take up the study in the Pakistani context, which hasnt been done yet. The results of hypothesis 1 are quite similar to earlier studies for example (Nguyen et al., 2011). Result of H2 was not as we have hypothesized. It may have different reasons, like awareness is a basic degree of knowledge about some brand but loyalty is the continuous preference and commitment towards a brand and a biased evaluation of a brand. It may involve experience for customer to reach loyalty. Or it may also be argued that there may be a series of mediating variables in this relationship.

The study results indicated that brand awareness causes $25.4 \%$ variation in brand loyalty with quite low degree of confidence, whereas, the negative and insignificant relationship was found between these two constructs. It is because; basic degree of knowledge must depend on source of knowledge. Majority population of Pakistan lives in a joint family system cannot be ignored, where our decisions are heavily influenced by the word of mouth. Similarly, as far as the selection of brands is concerned, people tend to pay 
attention to the general opinion of their friends, families, colleagues, etc. This creates awareness amongst people regarding brands, therefore leading to the purchase intention. But this however may not necessarily be enough to be loyal to that specific brand. But on the other hand, people in Pakistani culture dont rely too heavily on the advertisement before making a purchase decision, due to the high level of uncertainty avoidance. So consequently, it can be sufficient to deduce that brand loyalty is not only affected by the brand awareness but is influenced by how customers achieve that level of awareness and through which means. Furthermore perceived quality brings about $25.4 \%$ variations in brand loyalty with $100 \%$ confidence interval. The results indicate a positive relationship which has been significantly proven and supported by previous literature as well.

The moderating role of brand image on the relationship of brand awareness and brand loyalty as well as on the relationship of perceived quality was not proved. As per the results, brand image not only mediates the relationship between brand loyalty and its antecedents, it simultaneously moderates the said relationships. Literature provides ample evidences that brand image moderates the relationship between brand loyalty and its antecedents, both in service and manufacturing industries alike.

\subsection{Managerial implications}

This study and its results may prove useful for the managers while making decisions regarding the loyalty programs. The results suggest that it is imperative for the management to pay special attention to the advertising strategy which helps shape, mould and create the perception of the product in the eyes of the customers. As these findings suggest, perceived value of the product is of utmost importance and should play a vital role in formulating the awareness and loyalty programs.

\subsection{Limitations}

No study is without any certain limitations, therefore, so isnt the current study. The sample was drawn using convenient sampling technique which puts a limitation of the study, and hampers the generalization of the results on all regions. The data were also collected in one lag, which may be unable to cater to the changing market conditions over the period of time.

Lastly, data were collected from 4 major cities of the country. Data from across the country and region may provide more comprehensive and probably slightly different picture.

\subsection{Future Research}

For future research in the same area, a larger sample size, with data from across the country may help get a clearer picture and more generalized results. Similarly, same constructs should be explored in other product categories, from across the industries to gauge how different industries respond to the same constructs. Ultimately, the study can be expanded from merely focusing on the antecedents of the brand loyalty to the outcomes as well.

\section{References}

Aaker, D. A. (1996). Measuring brand equity across products and markets. California management review, 38(3):102.

Abu-ELSamen, A. A., Akroush, M. N., Al-Khawaldeh, F. M., and Al-Shibly, M. S. (2011). Towards an integrated model of customer service skills and customer loyalty: The mediating role of customer satisfaction. International Journal of Commerce and Management, 21(4):349-380.

Agrawal, D. (1996). Effect of brand loyalty on advertising and trade promotions: A game theoretic analysis with empirical evidence. Marketing science, 15(1):86-108.

Akram, A., Merunka, D., and Shakaib Akram, M. (2011). Perceived brand globalness in emerging markets and the moderating role of consumer ethnocentrism. International Journal of Emerging Markets, 6(4):291-303.

Al-Rousan, M. R. and Mohamed, B. (2010). Customer loyalty and the impacts of service quality: The case of five star hotels in jordan. International journal of human and social sciences, 5(13):886-892.

Alamro, A. and Rowley, J. (2011). Antecedents of brand preference for mobile telecommunications services. Journal of Product $\mathcal{E}$ Brand Management, 20(6):475-486.

Aravindakshan, A. and Naik, P. A. (2011). How does awareness evolve when advertising stops? the role of memory. Marketing Letters, 22(3):315-326.

Aurier, P. and Séré de Lanauze, G. (2011). Impacts of in-store manufacturer brand expression on perceived value, relationship quality and attitudinal loyalty. International Journal of Retail \& Distribution Management, 39(11):810-835.

Aydin, S. and Özer, G. (2005). The analysis of antecedents of customer loyalty in the turkish mobile telecommunication market. European Journal of marketing, 39(7/8):910-925.

Belaid, S. and Temessek Behi, A. (2011). The role of attachment in building consumer-brand relationships: an empirical investigation in the utilitarian consumption context. Journal of Product $\mathcal{E}$ Brand Management, 20(1):37-47.

Bianchi, C. and Pike, S. (2011). Antecedents of destination brand loyalty for a long-haul market: Australia's destination loyalty among chilean travelers. Journal of Travel $\mathcal{E}$ Tourism Marketing, 28(7):736-750. 
Brewer, A. and Zhao, J. (2010). The impact of a pathway college on reputation and brand awareness for its affiliated university in sydney. International Journal of Educational Management, 24(1):34-47.

Chan-Olmsted, S. M. and Cha, J. (2008). Exploring the antecedents and effects of brand images for television news: An application of brand personality construct in a multichannel news environment. The International Journal on Media Management, 10(1):32-45.

Chaudhuri, A. and Holbrook, M. B. (2001). The chain of effects from brand trust and brand affect to brand performance: the role of brand loyalty. Journal of marketing, 65(2):81-93.

Dodds, W. B., Monroe, K. B., and Grewal, D. (1991). Effects of price, brand, and store information on buyers' product evaluations. Journal of marketing research, pages 307-319.

Grunert, K. G. (2005). Food quality and safety: consumer perception and demand. European review of agricultural economics, 32(3):369-391.

Gupta, S., Melewar, T., and Bourlakis, M. (2010). Transfer of brand knowledge in business-to-business markets: a qualitative study. Journal of Business $\mathcal{E}$ Industrial Marketing, 25(5):395-403.

Herstein, R. and Zvilling, M. (2011). Brand management perspectives in the twenty-first century. Qualitative Market Research: An International Journal, 14(2):188-206.

Hofstede, G. (1984). The cultural relativity of the quality of life concept. Academy of Management review, 9(3):389-398.

Hsieh, A.-T. and Li, C.-K. (2008). The moderating effect of brand image on public relations perception and customer loyalty. Marketing Intelligence E Planning, 26(1):26-42.

Hur, W.-M., Ahn, K.-H., and Kim, M. (2011). Building brand loyalty through managing brand community commitment. Management Decision, 49(7):1194-1213.

Hyun Baek, T. and Whitehill King, K. (2011). Exploring the consequences of brand credibility in services. Journal of Services Marketing, 25(4):260-272.

Jacoby, J. and Kyner, D. B. (1973). Brand loyalty vs. repeat purchasing behavior. Journal of Marketing research, pages $1-9$.

Keller, K. L. (1993). Conceptualizing, measuring, and managing customer-based brand equity. the Journal of Marketing, pages 1-22.

Keller, K. L. (2003). Brand synthesis: The multidimensionality of brand knowledge. Journal of consumer research, 29(4):595600.

Lee, H.-M., Lee, C.-C., and Wu, C.-C. (2011). Brand image strategy affects brand equity after m\&a. European journal of marketing, 45(7/8):1091-1111.
Li, C.-K. and Hung, C.-H. (2009). Marketing tactics and parents' loyalty: The mediating role of school image. Journal of Educational Administration, 47(4):477-489.

Lin, L.-Y. (2010). The relationship of consumer personality trait, brand personality and brand loyalty: an empirical study of toys and video games buyers. Journal of Product $\mathcal{E}$ Brand Management, 19(1):4-17.

Liu, X. and Hu, M. Y. (2011). Umbrella brand price premiums: effects of compatibility, similarity, and portfolio size. Journal of Product $\mathcal{E}$ Brand Management, 20(1):58-64.

Liu, Y. (2007). The long-term impact of loyalty programs on consumer purchase behavior and loyalty. Journal of marketing, 71(4):19-35.

Louis, D. and Lombart, C. (2010). Impact of brand personality on three major relational consequences (trust, attachment, and commitment to the brand). Journal of Product $\mathcal{E}$ Brand Management, 19(2):114-130.

Luis Méndez, J., Oubina, J., and Rubio, N. (2011). The relative importance of brand-packaging, price and taste in affecting brand preferences. British Food Journal, 113(10):12291251.

Martinez, E. and De Chernatony, L. (2004). The effect of brand extension strategies upon brand image. Journal of consumer marketing, 21(1):39-50.

Matzler, K., Grabner-Kräuter, S., and Bidmon, S. (2008). Risk aversion and brand loyalty: the mediating role of brand trust and brand affect. Journal of Product $\mathcal{E}$ Brand Management, 17(3):154-162.

Møller Jensen, J. (2011). Consumer loyalty on the grocery product market: an empirical application of dick and basu's framework. Journal of Consumer Marketing, 28(5):333-343.

Müge Arslan, F. and Korkut Altuna, O. (2010). The effect of brand extensions on product brand image. Journal of Product $\mathcal{E}$ Brand Management, 19(3):170-180.

Nath Sanyal, S. and Datta, S. K. (2011). The effect of perceived quality on brand equity: an empirical study on generic drugs. Asia Pacific Journal of Marketing and Logistics, 23(5):604-625.

Nguyen, T. D., Barrett, N. J., and Miller, K. E. (2011). Brand loyalty in emerging markets. Marketing Intelligence $\mathcal{E}$ Planning, 29(3):222-232.

Punjaisri, K. and Wilson, A. (2011). Internal branding process: key mechanisms, outcomes and moderating factors. European Journal of Marketing, 45(9/10):1521-1537.

Radder, L. and Huang, W. (2008). High-involvement and lowinvolvement products: A comparison of brand awareness among students at a south african university. Journal of Fashion Marketing and Management: An International Journal, 12(2):232-243. 
Raimondo, M. A., " Nino" Miceli, G., and Costabile, M. (2008). How relationship age moderates loyalty formation: The increasing effect of relational equity on customer loyalty. Journal of Service Research, 11(2):142-160.

Rajagopal (2007). Buying decisions towards organic products: an analysis of customer value and brand drivers. International Journal of Emerging Markets, 2(3):236-251.

Raju, J. S., Srinivasan, V., and Lal, R. (1990). The effects of brand loyalty on competitive price promotional strategies. Management science, 36(3):276-304.
Srivastava, R. K. (2011). Understanding brand identity confusion. Marketing Intelligence $\mathcal{E}$ Planning, 29(4):340-352.

Taylor, S. A., Celuch, K., and Goodwin, S. (2004). The importance of brand equity to customer loyalty. Journal of product $\mathcal{E}$ brand management, 13(4):217-227.

Zeithaml, V. A. (1988). Consumer perceptions of price, quality, and value: a means-end model and synthesis of evidence. The Journal of marketing, pages 2-22. 